\title{
Diet of a Catfish before and after Damming of the Salto Caxias Reservoir, Iguaçu River
}

\author{
Rosilene Luciana Delariva ${ }^{1}$, Norma Segatti Hahn ${ }^{2} *$ and Luiz Carlos Gomes ${ }^{2}$ \\ ${ }^{1}$ Programa de Pós-graduação em Ecologia de Ambientes Aquáticos Continentais; NUPÉLIA; Universidade \\ Estadual de Maringá; Av. Colombo, 5790; 87020-900; rldelariva@uol.com.br; Maringá - PR - Brasil. \\ ${ }^{2}$ Universidade Estadual de Maringá; Núcleo de Pesquisas em Limnologia Ictiologia e Aquicultura - NUPÉLIA; Av. \\ Colombo, 5790; Bloco G-90; 87.020-900; Maringá - PR - Brasil.
}

\begin{abstract}
This study evaluated the diet of Pimelodus sp., before and after damming of Salto Caxias, (waterfall in the Iguaçu river), as well spatial and ontogenetic diet shift. Surveys were carried out from March 1997 to February 1998 (before damming) and from April 1999 to January 2000 (after damming) inside the reservoir and adjacent tributaries. Stomach contents analysis of 682 specimens revealed omnivory with high degree of trophic opportunism to this species. Analysis of variance (three way ANOVA) for scores produced from Detrended Correspondence Analysis (DCA) yielded a significant interaction between the damming phases and size of the individuals (juveniles and adults) $(F=4.68 ; P=0.04)$. After damming, adults exploited mainly fish, whereas the juveniles fed mostly on plants, dipterans larvae and scales at different sites. From significant differences in the ordination among the factors considered, it could be inferred that the diet of Pimelodus sp. was influenced by the formation of the reservoir and this depended on the life stage considered. Position of the sites (feeding grounds) did not lead to significant alterations in diet.
\end{abstract}

Key words: Catfish, diet, trophic opportunism, reservoir

\section{INTRODUCTION}

Most tropical fishes have variable diets and may exhibit high flexibility, ingesting all food items available in an aquatic environment. They also exhibit an acute ability to shift food quickly as a response to environment variations or food shortage. Therefore, changes in diet of fish over time and space may be a function of food resources availability (Hahn et al., 2004). However, alterations in habitats, such as reservoir formation that subject communities to sudden but intense changes in resource availability and may alter trophic relationships (Araújo-Lima et al.,
1995; Penczak, 1995), and provide insights into the mechanisms that structure the communities (Piet, 1998).

Reservoirs are common features of the landscape of Brazilian rivers, ecological studies on fish fauna, especially those dealing with influence of impoundments on feeding ecology, are few, the greater part unpublished (Gaspar da Luz, 2000; Mérona et al., 2001; Delariva, 2002; Vono, 2002; Loureiro-Crippa and Hahn, 2006). However, reservoirs represent a unique opportunity to evaluate the trophic adaptability (sensu Gerking, 1994) of neotropical fish.

\footnotetext{
* Author for correspondence
} 
The fish fauna of the Iguaçu river consists of about 64 species, and most of them are small and endemic to the basin (Garavello et al., 1997). Pimelodus sp. is one of the most abundant species captured in Salto Caxias and Segredo reservoirs, two impoundments in the Iguaçu. For this basin, one study examined the diet of Pimelodus sp. (= P. ortmanni) after the filling of the reservoir (Abujanra et al., 1999), but it did not compare the diet before and after the formation of the reservoir. The aim of this study was to examine the diet of the catfish Pimelodus sp., abundant in Salto Caxias reservoir, before and after its formation, expecting to answer the following question: did diet differ between natural and impacted environments taking in consideration sampling sites (feeding grounds)? As some neotropical fish experienced ontogenetic changes and environmental alterations could affect differently the life stages, they were also considered in the analysis. Therefore, it was expected to determine the most important source of variation to the species diet resulted from the impoundment.

\section{MATERIALS AND METHODS}

\section{Study area}

Samplings were carried out during the pre- and post-filling phases of Salto Caxias reservoir. The section of the Iguaçu river under study was dammed in October 1998 (located in the southwest region of the State of Paraná, $\left.25^{\circ} 32^{\prime} 35^{\prime \prime} \mathrm{S} / 53^{\circ} 29^{\prime} 43^{\prime \prime} \mathrm{W}\right)$. Sites sampled included tributaries [one site located upstream from their mouth (TU; tributaries upper sections), about 10 to $20 \mathrm{~km}$, not affected by the reservoir; and another 1 to $10 \mathrm{~km}$ above the connection with the Iguaçu river (TL; tributaries lower sections) which after dam closure, became lentic areas, the Tormenta, Adelaide, Guarani, Chopim and Jaracatiá rivers; the Cotejipe river, located downstream from the dam, with one sampling station], the main body of the river or reservoir (RI) and downstream from the dam (DO) (Fig. 1).
Samples were taken using three sets of 15 gillnets (mesh sizes ranging from 2.4 to $14.0 \mathrm{~cm}$ opposite knots) operated for $24 \mathrm{~h}$ and checked every $8 \mathrm{~h}$. Prior to the damming (pre-damming phase), samples were taken from March 1997 to February 1998, and after the closure of the dam (postdamming phase), from April 1999 to January 2000. All the individuals captured were measured (standard length, $\mathrm{cm}$ ) and weighed (total weight, g). The digestive tract was removed and fixed in $10 \%$ formalin.

Voucher-specimens have been deposited at the ichthyological collection of the Center for Research in Limnology, Ichthyology, and Aquaculture (Nupélia), NUP 1786 - (19 individuals) and NUP 1826 - (5 individuals), Salto Caxias reservoir, Iguaçu river basin, State of Paraná, Brazil, 2001, collected by Nupélia staff.

Stomach contents were analyzed and the volumetric method (percentage of volume) was used to express results. In order to evaluate ontogenetic changes in diet, individuals were separated (using the length of first maturation $=180 \mathrm{~mm}$ standard length $-\mathrm{SL}$, as criterion; Suzuki and Agostinho, 1997), in juveniles (< 180 $\mathrm{mm} \mathrm{SL}$ ) and adults (> $180 \mathrm{~mm} \mathrm{SL}$ ).

A multivariate ordination technique (detrended correspondence analysis - DCA; Hill and Gauch, 1980) was used to summarize the diet matrix (Sheldom and Meffe, 1993). Data entered in PCORD (MacCune and Mefford, 1997) controlling for phases (before and after the damming), sampling sites (feeding grounds) and life stage (juveniles and adults). Scores of this ordination were generated and submitted to a three way analysis of variance (ANOVA) using phases, feeding ground and life stage as factors (ANOVA terminology). Was adopted this protocol because it was difficult to meet ANOVA assumptions (normality: Shapiro Wilk; and homogeneity of variance: Test of Levene) using crude data. If assumptions were not met, scores were square root transformed. 


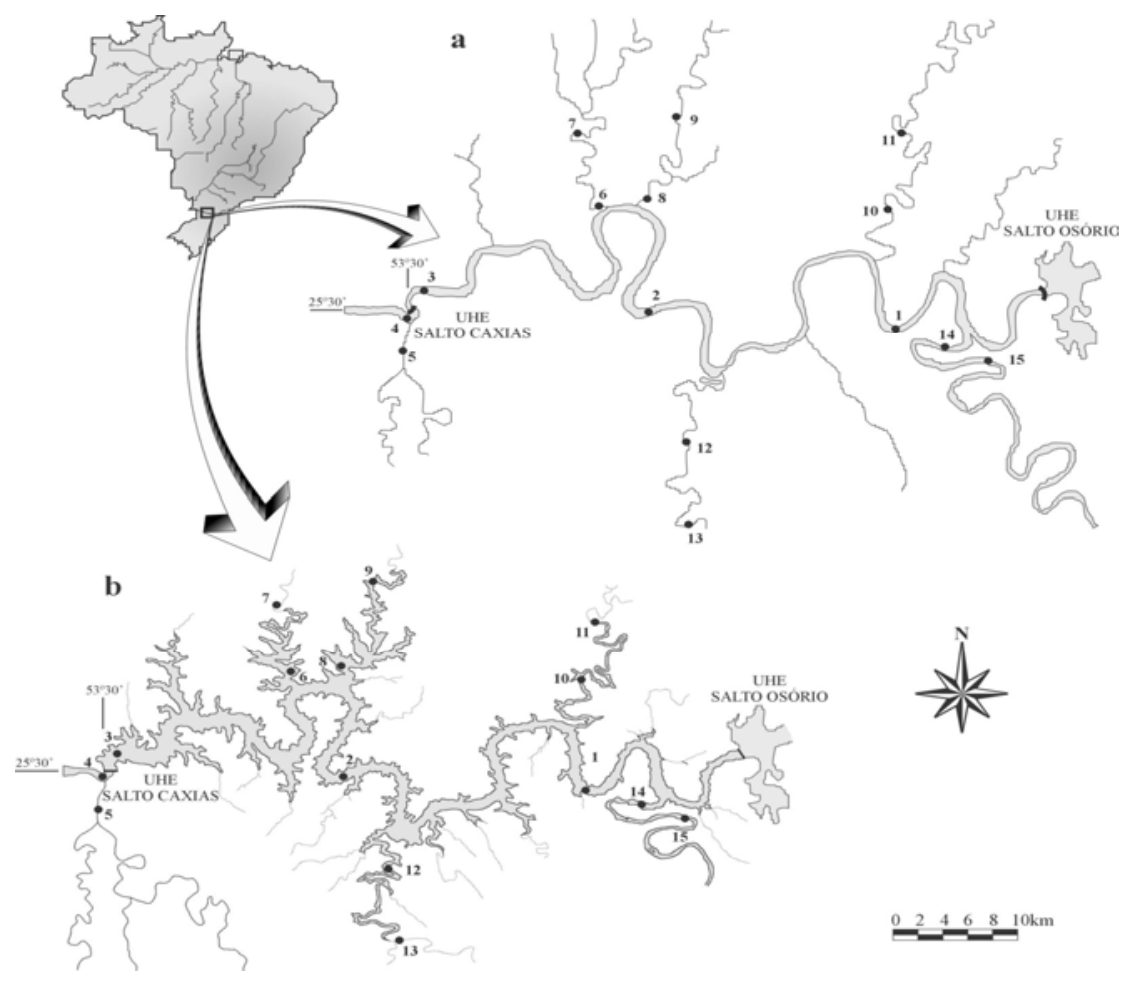

Figure 1 - Map of the studied area. Iguaçu river (a) and Salto Caxias reservoir (b) [sites 1 to 3 = main body of the river or reservoir (RI); 4 = downstream from the dam (DO); 5,7,9,11,13 and $15=$ tributaries upper sections (TU); 6, 8, 10, 12 and 14 $=$ tributaries lower sections $(\mathrm{TL})]$

\section{RESULTS}

\section{Diet composition}

Diet of 682 individuals (376 captured in the predamming phase and 306 in the post-damming phase) showed that this species fed on an extremely high diversity of resources ranging from invertebrates and vertebrates to plants and detritus (Table 1). In the pre-damming phase, juveniles preferentially consumed oligochaetes $(64.63 \%$ of the diet) in the tributaries upper sections (TU). In the other sampling stations, insect were important in the diet; however, no dominance of any táxon was observed. For adults, oligochaetes were also an important food item in tributaries upper sections $(\mathrm{TU}=47.5 \%)$, and in tributaries lower sections $(\mathrm{TL}=41.6 \%)$ as well. For the other sampling stations, as for juveniles, no food item was registered as dominant. But, after damming, juveniles consumed high proportion of plants in the tributaries lower sections (72\%), dipterans in the reservoir body ( $\mathrm{RI}=46.8 \%$ ) and scales in downstream from dam $(\mathrm{DO}=78.6 \%)$, whereas adults basically consumed fishes (Table 1).

\section{Changes in diet}

In order to better evaluate the changes in diet described above, was used a detrended correspondence analysis (DCA). The first two axes of the DCA were retained for interpretation, because they presented eigenvalues higher than 0.20 (as recommended by Matthews, 1998). Axis 1 (DCA1) presented an eigenvalue of 0.67 and axis 2 (DCA2), 0.30 .

For interpretation, the ordination was plotted considering the factors of interest. Then, diet of adults presented more variation considering the phases. This pattern is seen in axis 1 , where lower scores refer to juveniles (Fig. 2A) and adults (Fig. $2 \mathrm{~B})$ in the pre-damming phase, whereas higher scores refer to adults in the post-damming phase (Fig. 2B). For DCA2, the patterns were not clear, but there was a tendency of separating adults of 
different sites, but it appeared to be an effect of the phases (Fig. 3A and 3B).

Food items more important for the ordination were, negatively in DCA1, invertebrates (oligochaetes, mollusks and crabs), insects (aquatic and terrestrial) and plants and positively, fish. On DCA2, invertebrates and fish influenced positively the ordination whereas plants influenced negatively.

Table 1 - Volumetric frequency of the food items ingested by Pimelodus sp., considering life stages (juveniles and adults), phases (pre and post damming) and sites (feeding ground; $\mathrm{TU}=$ tributaries upper sections; $\mathrm{TL}=$ tributaries lower sections; $\mathrm{RI}=$ river channel or reservoir body; $\mathrm{DO}=$ downstream from the dam) ( $\mathrm{SL}=$ standard length). $\mathrm{A}=$ Aquatic; $\mathrm{T}=$ Terrestrial.

\begin{tabular}{|c|c|c|c|c|c|c|c|c|c|c|c|c|c|c|c|c|}
\hline \multirow[t]{3}{*}{ Food items } & \multicolumn{8}{|c|}{ Juveniles (60-180mm SL) } & \multicolumn{8}{|c|}{ Adults (181-330mm SL) } \\
\hline & \multirow[b]{2}{*}{ TU } & \multicolumn{2}{|c|}{ Pre } & \multicolumn{3}{|c|}{ Post } & \multirow[b]{2}{*}{ RI } & \multirow[b]{2}{*}{ DO } & \multicolumn{3}{|c|}{ Pre } & \multicolumn{5}{|c|}{ Post } \\
\hline & & TL & RI & DO & TU & TL & & & TU & TL & RI & DO & TU & TL & RI & DO \\
\hline Oligochaeta & 64.6 & 12.0 & 14.2 & 21.1 & & & & & 47.5 & 41.6 & 6.3 & 6.6 & & & & \\
\hline Arachnida & & 0.1 & 0.2 & 0.1 & 5.2 & 0.1 & 0.2 & & & & & & 0.1 & & & \\
\hline Decapoda (crabs) & & & & & & & & & 2.2 & 2.8 & 6.8 & 19.1 & 14.7 & 0.3 & 1.1 & 6.3 \\
\hline Mollusca & & 7.7 & 0.7 & & 4.1 & & 0.9 & 6.4 & 14.4 & 7.4 & 8.2 & 6.1 & 3.7 & 0.1 & & 2.7 \\
\hline Others invert. & & 0.2 & 0.2 & 0.2 & 0.6 & 4.0 & 2.4 & & & 0.2 & 0.1 & 0.1 & & & & \\
\hline Coleoptera (T) & & 2.2 & 6.2 & 7.4 & & 0.4 & & & 2.1 & 0.4 & 2.3 & 7.1 & & 0.7 & 1.2 & 0.1 \\
\hline Diptera (A) & 19.9 & 6.2 & 9.4 & 13.3 & 22.3 & 1.8 & 46.8 & 0.2 & 0.6 & 0.6 & 0.3 & 1.5 & 0.1 & 0.1 & & \\
\hline Ephemeroptera (A) & & 3.9 & 1.5 & 1.4 & 0.4 & 0.1 & 0.7 & & 0.4 & & 0.1 & 0.1 & 1.5 & & & \\
\hline Hymenoptera (T) & & 4.1 & 11.6 & 2.8 & & & & & 1.4 & 0.4 & 1.6 & 1.7 & & & & \\
\hline Lepidoptera (T) & 3.2 & 21.8 & 4.1 & 5.3 & 0.1 & & & & 0.8 & 2.9 & 0.6 & 1.0 & & & & \\
\hline Odonata (A) & & 0.5 & 0.2 & & 9.9 & & 0.7 & & 0.6 & 0.1 & 0.4 & 0.6 & 0.2 & 0.2 & & \\
\hline Trichoptera (A) & & 4.0 & 4.1 & 18.3 & 7.4 & 0.6 & 0.6 & & 0.6 & 0.3 & 0.2 & 0.2 & 0.4 & 0.4 & & \\
\hline Others insects (A) & 1.3 & 1.9 & 1.1 & 2.9 & 0.1 & 0.1 & & & 0.5 & 1.5 & 1.6 & 1.9 & 0.1 & 0.1 & & \\
\hline Others insects $(\mathrm{T})$ & 4.5 & 0.3 & 1.7 & 5.7 & & & & 1.2 & 0.9 & 2.1 & 0.1 & 0.4 & & 0.1 & & \\
\hline Insect remain & & 5.4 & 3.3 & 1.8 & 2.2 & 0.5 & 0.4 & 0.1 & 0.3 & 0.5 & & 0.1 & 0.1 & 0.1 & 0.1 & \\
\hline Astyanax sp. & & & & & & & & & & 5.7 & & 0.9 & 42.3 & 6.3 & 18.8 & 18.7 \\
\hline Cichlidae & & & & & & & & & & & & 0.5 & 6.6 & 2.1 & 1.3 & \\
\hline Pimelodidae & & & & & & & & & & & 7.5 & & & 1.2 & 11.0 & 12.3 \\
\hline Gymnotiformes & & & & & & & & & & & & 0.3 & 22.0 & 6.2 & 2.6 & \\
\hline Scales & & 1.4 & 6.8 & & 31.6 & 6.1 & 12.1 & 78.6 & 0.2 & & 2.6 & 0.9 & & 0.5 & 0.2 & \\
\hline Fish remain & & 0.4 & 1.1 & & & 1.5 & & & 15.2 & 8.4 & 38.8 & 23.9 & 4.8 & 61.4 & 54.5 & 59.6 \\
\hline Aquatic plants & & 4.7 & 9.0 & 0.8 & & & & 5.7 & 1.2 & 3.6 & 5.6 & 5.2 & & & & \\
\hline Terrestrial plants & & 6.4 & 18.6 & 4.8 & 10.3 & 72.0 & 24.3 & 2.6 & 6.8 & 15.7 & 11.0 & 17.9 & 2.9 & 19.7 & 9.1 & 0.4 \\
\hline Detritus/sediment & 6.4 & 16.6 & 5.9 & 14.1 & 5.8 & 12.8 & 10.8 & 5.1 & 4.2 & 5.8 & 5.7 & 3.6 & 0.3 & 0.6 & 0.1 & \\
\hline Numbers of Stomach & 2 & 21 & 137 & 13 & 7 & 22 & 13 & 24 & 16 & 43 & 108 & 36 & 13 & 100 & 79 & 48 \\
\hline
\end{tabular}



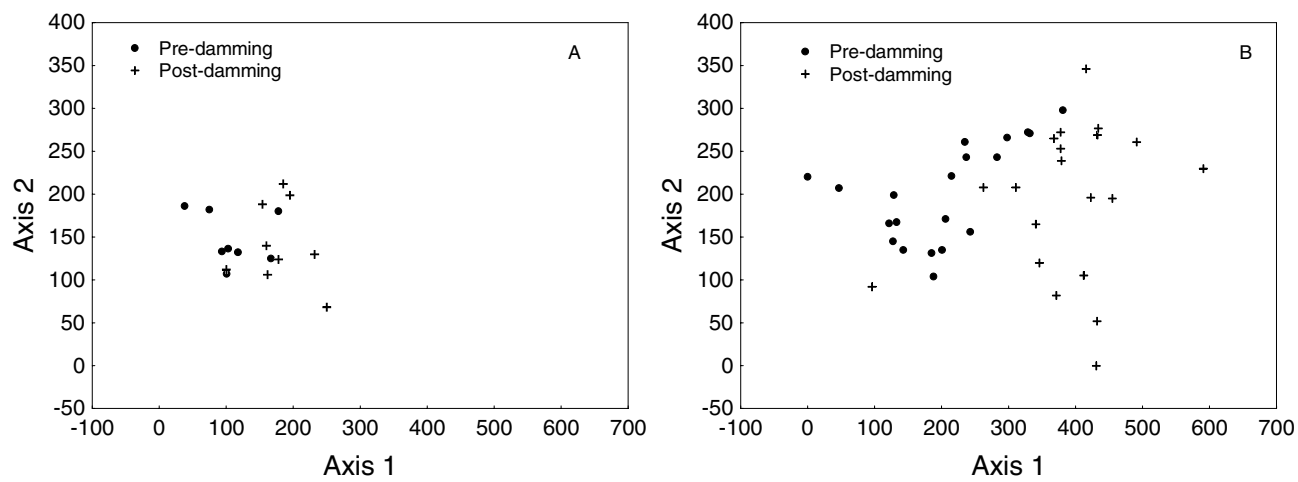

Figure 2 - Scores derived from Detrended Correspondence Analysis (DCA) applied on the diet data of Pimelodus sp., considering life stages (juveniles - A; adults B) and phases
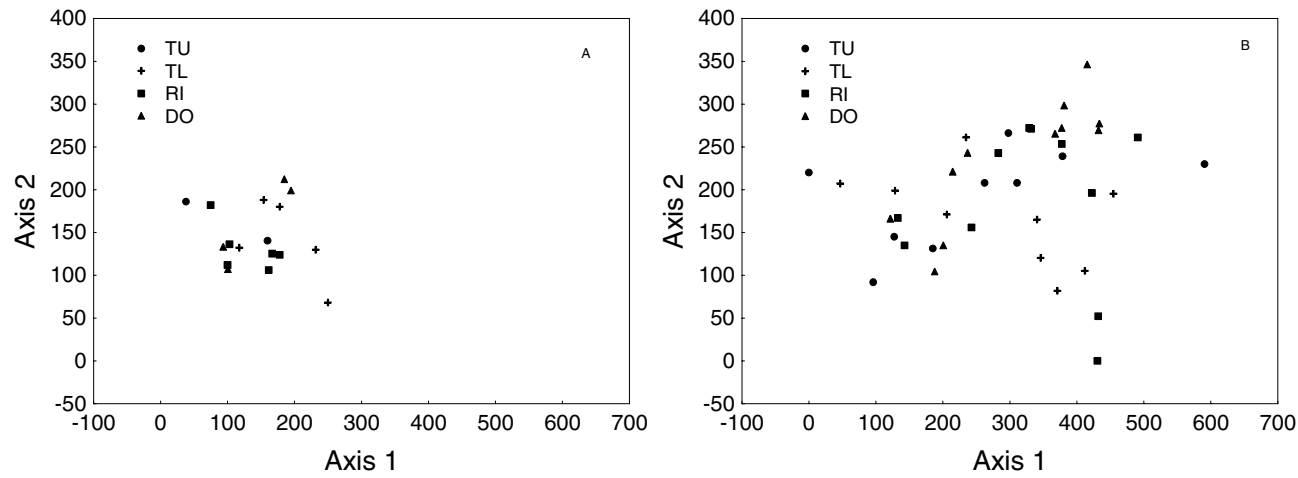

Figure 3 - Scores derived from Detrended Correspondence Analysis (DCA), applied on the diet data of Pimelodus sp., considering life stages (juveniles - A; adults B) and feeding grounds (sampling sites grouped). $\mathrm{TU}=$ tributaries upper sections; $\mathrm{TL}=$ tributaries lower sections; $\mathrm{RI}=$ river channel or reservoir body; $\mathrm{DO}=$ downstream from the dam

The three way ANOVA applied on the scores of DCA1 and DCA2 using phase (before and after damming), sampling sites (TU, TL, RI and DO; feeding ground) and life stages (juveniles and adults) helped to evaluate if the patterns found differed statistically. Assumptions required for the test were met (normality: Shapiro Wilk - P > 0.05; and homogeneity of variance: $\mathrm{F}$ of Levene $-\mathrm{P}>$ $0.05)$ for DCA1. For this axis, the three order interaction was not significant, indicating that the two order interaction could be interpreted (Table $2)$. The interaction between phase $*$ life stage was significant $(\mathrm{F}=4.68 ; \mathrm{P}=0.04)$. Then, the position of the scores of the life stages on the ordination depended on the phase considered, i.e., juveniles presented few changes in diet whereas adults presented relevant changes (this pattern was clear in Fig. 4A and 4B, for axis 1). For axis 2, the assumption of homogeneity of variance was not met. Then, data were square root transformed to overcome the problem. After transformation, no significant differences among the factors considered and respective interactions was found (Table 2; Fig. 4C and 4D).

Once determined the significant differences in the ordination among the factors considered, it could be infered that the diet of Pimelodus sp. was influenced by the formation of the reservoir and 
this depended on the life stage considered.

to significant alterations in diet.

Position of the sites (feeding grounds) did not lead

Table 2 - Results of the three way ANOVA applied to the scores of the detrended correspondence analysis (DCA) that summarized diet data of Pimelodus sp., in the Salto Caxias reservoir, PR. ( $\mathrm{df}=$ degrees of freedom; $\mathrm{F}=$ ANOVA statistic; $\mathrm{P}=$ probability of finding an $\mathrm{F}$ greater than the one found; values in bold were significant, $\mathrm{p}<0,05)$.

\begin{tabular}{lcccccc}
\hline Factors & \multicolumn{3}{c}{ Axis 1 } & \multicolumn{2}{c}{ Axis 2 } \\
& df & F & P & df & F & P \\
\hline Phases & 1 & 25.52 & $<\mathbf{0 . 0 0 1}$ & 1 & 0.40 & 0.53 \\
Life stages & 1 & 32.13 & $<\mathbf{0 . 0 0 1}$ & 1 & 2.74 & 0.11 \\
Sites & 3 & 0.93 & 0.44 & 3 & 1.28 & 0.30 \\
Phases * life stage & 1 & 4.68 & $\mathbf{0 . 0 4}$ & 1 & 0.09 & 0.77 \\
Phases * sites & 3 & 0.14 & 0.93 & 3 & 2.67 & 0.06 \\
Sites * life stages & 3 & 1.09 & 0.36 & 3 & 0.23 & 0.88 \\
Phases * sites * life stages & 3 & 0.23 & 0.87 & 3 & 0.23 & 0.88 \\
\hline
\end{tabular}

\section{DISCUSSION}

The feeding spectrum of Pimelodus sp. allowed to infer where and how the species acquired the food. The consumption of insect larvae, mollusks, crabs and detritus/sediment denoted feeding on the bottom, while the explotation on terrestrial worms (oligochaetes), terrestrial insect and plants (mainly fruits) indicated that the species intakes drifting material on water surface. Therefore, it was inferred may infer that this species fed on all available food items in different layers of the water column, independent on sampling stations, and then, exploring available trophic levels. Abujanra et al. (1999) classified this species in Segredo reservoir, PR, as omnivore. This tendency was verified in several studies on species of the same genus, such and Pimelodus maculatus (BasileMartins et al., 1986; Lolis and Andrian, 1996; Lóbon-Cerviá and Bennemann, 2000). On the other hand Abes et al (2001) observed that another species of Pimelodidae (Iheringichthys labrosus) fed only on the bottom in the Itaipu reservoir.

It is known that where species of Pimelodus are present, they usually are abundant, either in number of individuals or biomass, and play a relevant role in the ecosystem. Therefore, they have great capacity to establish themselves in lentic environments (Abujanra et al., 1999; Lima-Júnior and Goitein, 2004). This ability may be associated with the capacity of this species to explore diverse niches, in addition to the opportunistic feeding behaviour. The fact that juveniles and adults consumed high quantities of terrestrial worms in the tributaries (both upper and lower section), in the pre damming phase confirmed the opportunism of the species, because this resource might have become available in the water after being carried by run off resulted from rains in the region.

Based on the several feeding tatics of Pimelodus sp. and on some studies that identified ontogenetic diet shifts in P. maculatus (BasileMartins et al., 1986; Lima-Júnior and Goitein, 2003), the diet of juveniles and adults of Pimelodus sp. was examined separately. Therefore, considering life stage, the diet of juveniles overall was based on arthropods (mainly insects). However, for adults, fish presented greater contribution to the diet. In fact, the few papers that consider ontogenetic diet shift of these catfishes (Basile-Martins et al., 1986; Lima-Júnior and Goitein, 2003) describe tendecy to piscivory for adults. Although the mouth of Pimelodus is subinferior and favours intake of food from a substrate (Lolis and Andrian, 1996; Lóbon-Cerviá and Bennemann, 2000), this does not impede the species to explore other compartments of the environment, broadening its trophic niche. Juveniles ingested especially insect larvae, probably exploited near marginal areas, while adults, due to their greater ability to ingest large prey, concentrated their diets on other fish species (caracids, pimelodids, ciclids), especially in the main body of the reservoir that did not have any shelter in tributaries lower sections and downstream from the dam. For Pimelodus sp. evidences of the 
piscivorous habit for adults were records of the ingestion of fish (taken whole and we could identify them) or fish remains (in advanced stage of digestion, but whole ingested).
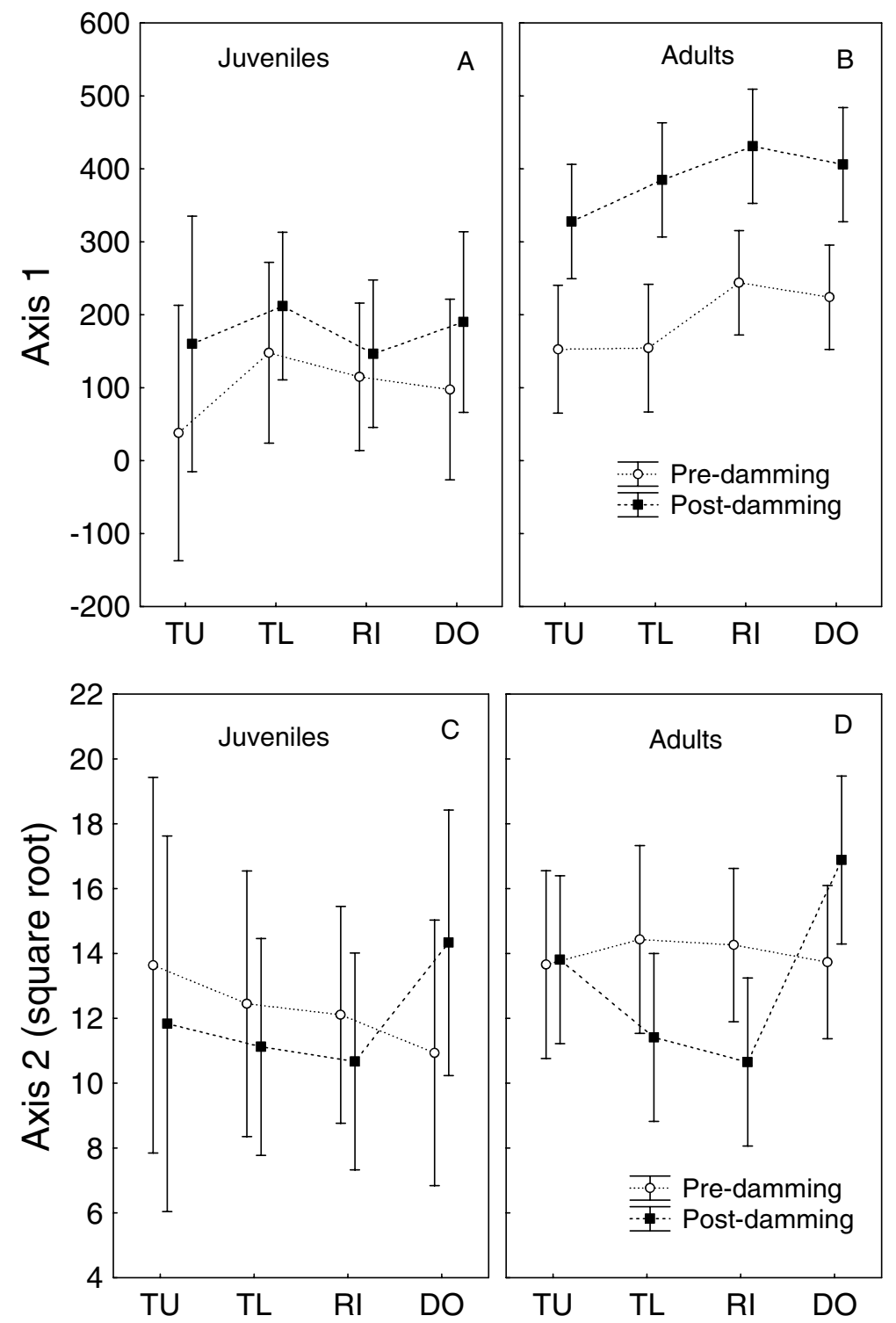

Figure 4 - Results of the three way analysis of variance (ANOVA) applied on the scores (axis 1, A and B; and axis 2, C and D) of a Detrended Correspondence Analysis (DCA). Factors were life stages (juveniles and adults), phases (pre and post-damming), and sampling sites ( $\mathrm{TU}=$ tributaries upper sections; $\mathrm{TL}=$ tributaries lower sections; RI = main body of the river or reservoir; and DO = downstream from the dam)

During the filling stage of a reservoir and for some time immediately afterward, fish also become food items temporarily used by non-piscivores fish.
This happens when fish mortality occurs, and generally medium-sized species that are capable of tearing fish apart, successfully use this new 
available resource, behaving as necrophages. Leporinus and Pimelodus have used this resource widely after impoundments (Hahn and Fugi, unpublished data). Leporinus friderici consumed a large quantity of fish parts during the formation of the Manso reservoir, State of Mato Grosso (Balassa et al., 2004). Pimelodus sp. was characterized in this study as highly opportunistic in every environment disturbed by the impoundment (TL, RI and DO) ingesting large proportions of fish (scales among the juvenilles and fragments of muscle among the adults) after this event. According to Agostinho and Júlio Jr. (1999), piscivory among fish is mandatory for some species and opportunistically for others that act temporarily, taking advantage of high densities of prey. Lolis and Andrian (1996) reported the great opportunism of $P$. maculatus in the upper Paraná river floodplain during the dry phases, when prey fishes were more available and comprised $50 \%$ of the species diet.

In the case of Pimelodus sp., this tendency was more pronounced for adults, whose diets differed significantly after the impoundment, indicating that the reservoir (pre and post damming phases) and the development stage of the individuals were decisive in this change. Although juveniles presented wide variation in the feeding spectrum, they did not change feeding habit after the reservoir was formed (except individuals collected in TL, whose stomachs presented plants, and in DO, with scales, both contributing to more than 70\%). These differences between feeding behavior of juveniles and adults in fishes indicated trophic niche segregation, probably reducing intraspecific competition.

\section{ACKNOWLEDGMENTS}

We thank Copel, Nupélia (núcleo de Pesquisas em limnologia, Ictiologia e Aquiicultura) and the postgraduate course in Ecologia de Ambientes Aquáticos Continentais da Universidade Estadual de Maringá for their support.

\section{RESUMO}

Esse estudo avaliou a dieta de Pimelodus sp., antes e após o represamento de Salto Caxias, no rio Iguaçu, bem como variações espaciais e ontogenéticas na dieta da espécie. As amostragens foram realizadas antes do represamento (março/97 a fevereiro/98) e no período posterior (abril/99 a janeiro/00), no corpo principal do reservatório e tributários adjacentes. A análise de conteúdos estomacais de 682 exemplares revelou que esta espécie é onívora com elevado oportunismo trófico. Após o represamento, indivíduos adultos exploraram principalmente peixes, enquanto que os juvenis consumiram especialmente plantas, larvas de Diptera e escamas em diferentes locais de coleta. A análise de variância (ANOVA trifatorial) aplicada sobre os escores da análise de correspondência com remoção do efeito do arco (DCA), mostrou uma interação significativa ( $\mathrm{F}=$ 4.68; $\mathrm{P}=0.04)$ entre as fases de represamento e o tamanho dos indivíduos (juvenis e adultos). Uma vez determinada as diferenças significantes na ordenação entre os fatores considerados, nós podemos inferir que a dieta de Pimelodus sp. foi influenciada pela formação do reservatório e isso dependeu do tamanho dos indivíduos. As análises por locais de coleta não mostraram diferenças significantes na dieta.

\section{REFERENCES}

Abes, S. S., Agostinho, A. A., Okada, E. K. and Gomes, L. C. (2001) Diet of Iheringichthys labrosus (Pimelodidae, Siluriformes) in the Itaipu Reservoir, Paraná River, Brazil-Paraguay. Brazilian Archives of Biology and Technology, 44: (1), 101-105.

Abujanra, F., Russo, M. R. and Hahn, N. S. (1999), Variações espaço-temporais na alimentação de Pimelodus ortmanni (Siluriformes, Pimelodidae) no reservatório de Segredo e áreas adjacentes (PR). Acta Scientiarum, 21: (2), 283-289.

Agostinho, A. A. and Júlio Jr. H. F. (1999), Peixes da bacia do alto rio Paraná. In- Lowe-McConnell, R. H. Estudos ecológicos de comunidades de peixes tropicais. Tradução: Vazzoler, A. E. A., Agostinho, A. A. and Cunnhingham, A. A. Edusp, São Paulo. pp. 374-400.

Araújo-Lima, C. A. R. M., Agostinho, A. A. and Fabré, N. N. (1995), Trophic aspects of fish communities in Brazilian rivers and reservoir. In- Tundisi, J. G., Bicudo, C. E. M. and Matsumura-Tundisi, T. (Eds.) Limnology in Brazil. Rio de Janeiro, ABC/SBL. pp. 105-136.

Balassa, G. C., Fugi, R, Hahn, N. S. and Galina, A. B. (2004). Dieta de espécies de Anostomidae (Teleostei, Characiformes) na área de influência do reservatório de Manso, Mato Grosso, Brasil. Iheringia, 94: (1), 77-82. 
Basile-Martins, M. A., Cipoli, M. N. and Godinho, H. M. (1986), Alimentação do mandi, Pimelodus maculatus Lacépède, 1803 (Osteichthyes, Pimelodidae), de trechos dos rios Jaguari e Piracicaba, São Paulo - Brasil. B. Inst. Pesca, 13: (1), 17-29.

Delariva, R. L. (2002), Ecologia trófica da ictiofauna do rio Iguaçu, PR. e efeitos do represamento de Salto Caxias. PhD. Thesis, Universidade Estadual de Maringá, Maringá.

Garavello, J. C., Pavanelli, C. S. and Suzuki, H. I. (1997), Caracterização da ictiofauna do rio Iguaçu. In- Agostinho, A. A. and Gomes, L. C. Reservatório de Segredo: bases ecológicas para o manejo. Eduem, Maringá. pp. 61-84.

Gaspar da Luz, K. D. (2000), Espectro alimentar $e$ estrutura trófica da ictiofauna do reservatório da UHE Corumbá-GO. Unpublished Dissertation, Universidade Estadual de Maringá, Maringá.

Gerking, S. D. (1994), Feeding Ecology of Fish. New York, Academc Press.

Hahn, N.S., Fugi, R. and Andrian, I.F. (2004), Trophic ecology of the fish assemblages. In: Thomaz, S. M., Agostinho, A. A. and Hahn, N. S. (Eds.) The Upper Paraná River and its Floodplain: Physical aspects, Ecology and Conservation. Backhuys Publishers, Leiden, The Netherlands. pp. 247-269.

Hill, M. O. and Gauch, H. G. (1980), Detrended correspondence analysis, an improved ordination technique. Vegetatio, 42, 47-58.

Lima-Júnior, S. E. and Goitein, R. (2003), Ontogenetic diet shifts of a Neotropical catfish, Pimelodus maculatus (Siluriformes, Pimelodidae): A ecomorphological approach. Environ. Biol. Fishes. 68, 73-79.

Lima-Júnior, S. E. and Goitein, R. (2004), Diet and feeding activity of Pimelodus maculatus (Osteichthyes, Pimelodidae) in the Piracicaba River (State of São Paulo, Brazil)- The effect of seasonality. B. Inst. Pesca, 30 : (2), 135-140.
Lobón-Cerviá, J. and Bennemann, S. T. (2000), Temporal trophic shifts and feeding diversity in two sympatric, neotropical, omnivorous fishes: Astyanax bimaculatus and Pimelodus maculatus in Rio Tibagi (Paraná, Southern Brazil). Arch. Hydrobiol., 149: (2), 285-306.

Lolis, A. A. and Andrian, I. F. (1996), Alimentação de Pimelodus maculatus Lacépède, 1803 (Siluriformes, Pimelodidae) na planície de inundação do alto rio Paraná, Brasil. B. Inst. Pesca, 23, 187-202.

Loureiro-Crippa, V. E. and Hahn, N. S. (2006), Use of food resources by the fish fauna of a small reservoir (rio Jordão, Brazil) before and shortly after its filling. Neotropical Ichthyology. 4 (3): 357-362.

MacCune, B and Mefford, M. J. (1997), Multivariate analysis of ecological data, version 3.0. Oregon, USA, MjM Software Design.

Mérona, B., Santos, G. M. and Almeida, R. G. (2001), Short term effects of Tucuruí Dam (Amazonia, Brazil) on the trophic organization of fish communities. Environ. Biol. Fishes. 60, 375-392.

Penczak, T. (1995), Food consumption by populations in the Warta River, Poland, before and after impoundment. Hydrobiologia, 302: (1), 47-61.

Piet, G. J. (1998), Impact of environmental perturbation on a tropical fish community. Can. J. Aquat. Sci., 55, 1842-1853.

Sheldon, A. L. and Meffe, G. K. (1993), Multivariate analysis of feeding relationships of fishes in blackwater streams. Environ. Biol. Fishes, 37, 161171.

Suzuki, H. I. and Agostinho, A. A. (1997), Reprodução de peixes do reservatório de segredo. In- Agostinho, A. A. and Gomes, L. C. (Eds.). Reservatório de Segredo: bases ecológicas para o manejo. Eduem, Maringá. pp. 163-182.

Vono, V. (2002), Efeitos da implantação de duas barragens sobre a estrutura da comunidade de peixes do rio Araguari (Bacia do Alto Paraná, MG). PhD. Thesis, Universidade Federal de Minas Gerais, Belo Horizonte. 